\title{
Distribution of Pogonophora (tube-worms) in British Columbian fjords
}

\author{
A. J. Southward, E. C. Southward \\ Leverhulme Unit, Marine Biological Association, Plymouth PL1 2PB, United Kingdom \\ and \\ Department of Biology, University of Victoria, British Columbia, Canada V8W 2 Y2
}

\begin{abstract}
The large perviate pogonophore Polybrachia canadensis, previously known from deep water off the west coast of British Columbia (B.C.), Canada, and from Tasu Inlet on the west side of the Queen Charlotte Islands, has been found at 6 stations along Rivers Inlet/Moses Inlet, a mainland B.C. fjord complex opening from Queen Charlotte Sound. The pogonophore was a dominant element in the benthic macrofauna. It was not found in samples from nearby Seymour and Belize Inlets, a smaller and shallower fjord complex to the south of Rivers Inlet. Pogonophora have not been seen in any samples from the southern B.C. fjords sheltered by Vancouver I. or the inlets along its west coast. Perviate pogonophorans such as Polybrachia live in reducing sediments and are nourished by endosymbiotic chemoautotrophic bacteria that derive energy from particulate sulphides in the sediment. It is unlikely that reducing conditions that produce such sulphides are any different in the southern B.C. fjords. Explanations suggested for the differences in distribution of the pogonophores include greater density and stability of the bottom waters of the northern fjords and their proximity to the deep sea population. The presence of a sizeable deep-sea pogonophore at 200 to $300 \mathrm{~m}$ depth in the northern B.C. fjords is not paralleled in the Norwegian fjords
\end{abstract}

\section{INTRODUCTION}

Between 1950 and 1972 an extensive survey of the invertebrate fauna of British Columbian (B.C.) waters was carried out by the Fishery Research Board of Canada under the direction of Dr D.B. Quayle. The main purpose was to assess the shellfish resources of the Province, but all the invertebrate macrofauna was included in the census, which ranged over an area from the mainland fjords to the continental slope outside Vancouver Island and the Queen Charlotte Islands down to $2500 \mathrm{~m}$. Between 1964 and 1966, the survey recovered large samples of Pogonophora from certain open sea localities and from Tasu Inlet in the Queen Charlotte Is. (Southward 1969a). The dominant pogonophore, Polybrachia canadensis (Ivanov), was abundant enough to provide a basis for describing growth of the animals and tubes (Southward 1969b). This species has stiff brown tubes 0.4 to $1.0 \mathrm{~mm}$ diameter anteriorly, paler brown and narrower posteriorly. The tubes are up to $50 \mathrm{~cm}$ long and are quite conspicuous in dredge hauls and preserved samples. Since these first publications on their occurrence in B.C. waters it has been discovered that pogonophorans, with one known exception, are dependent for their nutrition on symbiosis with internal chemoautotrophic bacteria that obtain energy by oxidation of reduced sulphur compounds, probably particulate iron sulphides; the exception lives in symbiosis with a methanotrophic bacterium (Southward 1987, Southward \& Dando 1988, Southward \& Southward 1988, Schmaljohann \& Flügel 1987). This discovery of an unusual means of nutrition is of fundamental importance in explaining the distribution of the group.

Recently the authors were privileged to examine samples collected during additional invertebrate surveys by Dr Quayle and his associates in 1967, 1968 and 1972. Pogonophores were found again in Tasu Inlet, but more surprisingly they also occurred at several stations in Rivers Inlet/Moses Inlet, a mainland fjord complex opening off Queen Charlotte Sound. The new specimens all belong to Polybrachia canadensis.

The new locations for pogonophores are listed here together with the earlier records, and some tentative conclusions drawn about the factors controlling the distribution of Pogonophora in B.C. waters. 


\section{MATERIAL, METHODS AND ENVIRONMENTAL BACKGROUND}

Records of the invertebrate surveys carried out by the Fishery Research Board of Canada up to 1972 are held in computer files at the Pacific Biological Station, Nanaimo; the investigation was colloquially known as the 'clam survey'. Lists were produced for groups of years up to 1972, as part of the Manuscript Report Series of the Fisheries Research Board. One of the earlier lists also includes all benthic sampling carried out along the British Columbian coast back to 1878 . The lists of most interest in the present context are those prepared by Bernard et al. $(1967,1968,1970)$ and by Bernard \& Quayle (1973). The 1972 stations in Rivers Inlet are not included in the last of these lists, and we are indebted to Dr D.B. Quayle for supply of data abstracted from field records and records of sample sorting.

The cumulative coverage of the B.C. fjords and open coast provided by the extensive sampling programme and its predecessors up to 1972 is shown in Fig. 1. Since the aim of the survey was to explore as much as possible of the Provincial marine resources the sampling methods used were qualitative, or at best semiquantitative, in character. No statistical treatment is therefore possible. The catches were sorted on deck and preserved soon after collection. The gear used dredges and small trawls - is listed in Table 1, which also includes all available records of Polybrachia canadensis. The pogonophore samples were quantified with reference to the volume preserved, an abundant sample being one that required a jar of 1 l or more; the lowest category was 'present', less than 10 pogonophore tubes, while the 'common' category is more than 10 tubes but less than a $1 \mathrm{l}$ jar. The rest of the macrofauna were usually, but not always, noted in the biological log sheets, and such data, where available, are included in Table 1.

The mollusc and brachiopod species collected during the survey have been listed by Bernard $(1970,1971)$, who also used some of the material for studies of the taxonomy, morphology and functional anatomy of bivalves (Bernard 1972, 1974, 1978).

The coastline of B.C. is extensively dissected into long fjord complexes which vary in their hydrography. Pickard (1961) has classified them into northern, intermediate and southern categories. The northern mainland fjords opening off Hecate Strait and Queen Charlotte Sound have more stable hydrographic regimes than the southern group. There is greater oceanic influence in the northern fjords where the bottom water

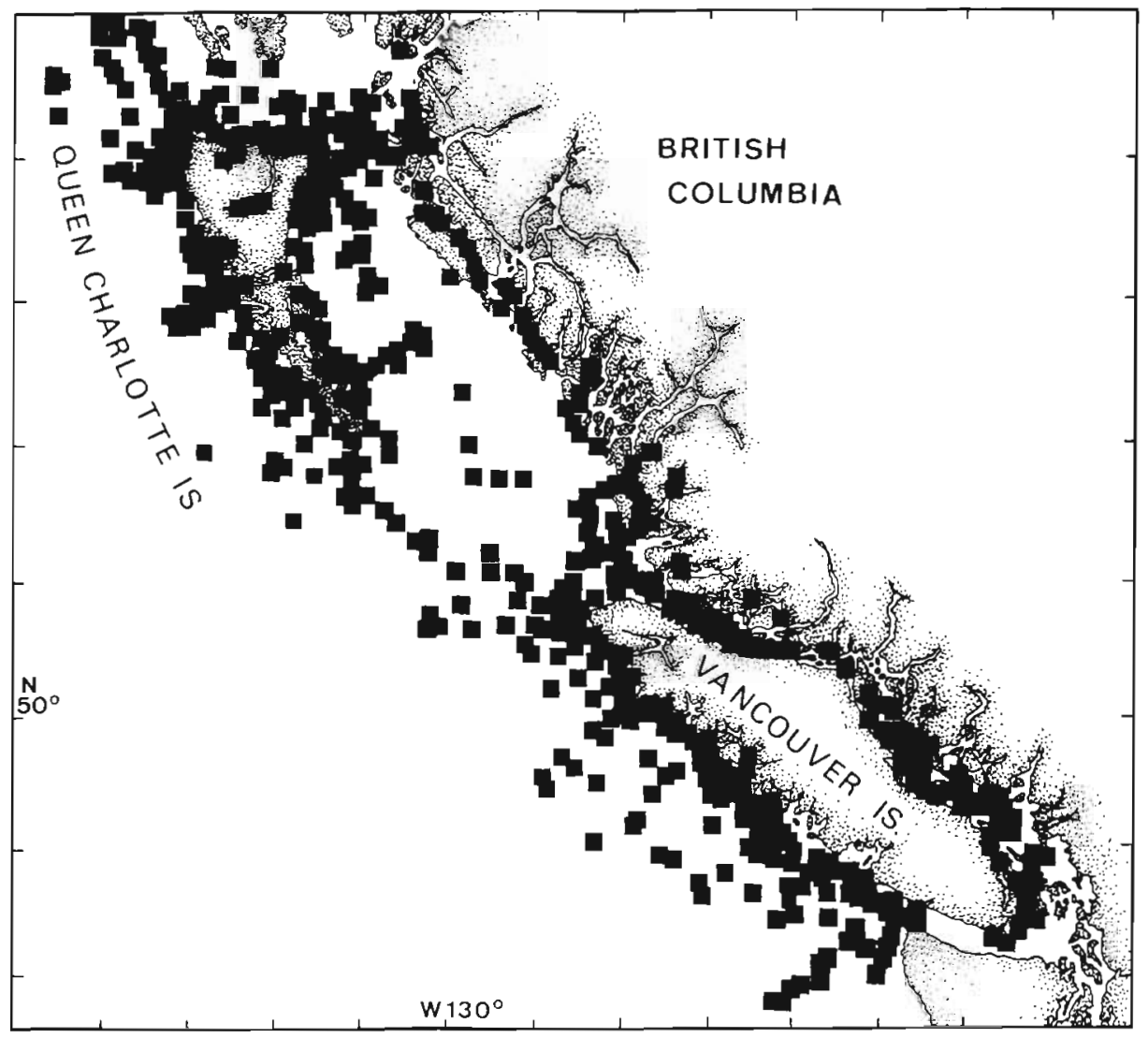

Fig. 1 Cumulative map of benthic sampling stations in British Columbian waters and nearby Pacific Ocean from 1878 to 1972 . It is not possible to show all individual stations on this scale and many of the squares represent several samples 
Table 1. Occurrence of Polybrachia canadensis (Pogonophora) in British Columbian waters; bottom nature and associated fauna. Benthic gear used: Agassiz Trawl (A.T.); circular dredge (C.D.); naturalists dredge (N.D.); natualists trawl (N.T.); rock dredge (R.D.); triangular dredge (T.D.). Abundances categories for Pogonophora in the samples: " present; ' common; -.. pogonophores abundant (over 11 preserved)

\begin{tabular}{|c|c|c|c|c|c|c|c|}
\hline Stn & Date & Gear & Position & $\begin{array}{l}\text { Depth } \\
(\mathrm{m})\end{array}$ & Bottom & $\begin{array}{l}\text { Pogono- } \\
\text { phore } \\
\text { abund- } \\
\text { ance }\end{array}$ & $\begin{array}{l}\text { Other macrofauna } \\
\text { or reference }\end{array}$ \\
\hline - & - & A.T & $\begin{array}{l}\text { Off Dixon Entrance, north-west } \\
\text { of Queen Charlotte Islands } \\
54^{\circ} \mathrm{N}, 134^{\circ} \mathrm{W}\end{array}$ & $2500-2600$ & - & $\cdot$ & (Ivanov 1962) \\
\hline $64-207$ & $10 \operatorname{Sep} 64$ & N.D. & $\begin{array}{l}\text { Southwest of Cape Scott } \\
50^{\circ} 32^{\prime} \mathrm{N}, 129^{\circ} 01.5^{\prime} \mathrm{W} \text { to } \\
50^{\circ} 33^{\prime} \mathrm{N}, 129^{\circ} 02^{\prime} \mathrm{W}\end{array}$ & $1829-1874$ & Mud & $\cdots$ & $\begin{array}{l}\text { Gephyreans, ophiuroids, } \\
\text { holothurians, scalpellids }\end{array}$ \\
\hline $64-208$ & 11 Sep 64 & R.D. & $\begin{array}{l}\text { Southwest of Cape Scott } \\
50^{\circ} 32^{\prime} \mathrm{W}, 129^{\circ} 01^{\prime} \mathrm{W} \text { to } \\
50^{\circ} 32^{\prime} \mathrm{N}, 129^{\circ} 03^{\prime} \mathrm{W}\end{array}$ & 1829 & - & $\cdots$ & $\begin{array}{l}\text { Sponges, gorgonians, } \\
\text { shrimps, polychaetes }\end{array}$ \\
\hline $65-37$ & 03 Aug 65 & N.T & $\begin{array}{l}\text { Off Cox island } \\
50^{\circ} 32^{\prime} \mathrm{N}, 129^{\circ} 00^{\prime} \mathrm{W}\end{array}$ & 1884 & Mud & $\cdots$ & $\begin{array}{l}\text { Sponges, gorgonians } \\
\text { turbellarian eggs, } \\
\text { gephyreans, polychaetes }\end{array}$ \\
\hline $65-42$ & 04 Aug 65 & N.T & $51^{\circ} 47^{\prime} \mathrm{N}, 131^{\circ} 31^{\prime} \mathrm{W}$ & 1876 & - & $\cdots$ & - \\
\hline $65-47$ & 05 Aug 65 & N.T & $\begin{array}{l}\text { Off Cape St. James } \\
51^{\circ} 27^{\prime} \mathrm{N}, 131^{\circ} 48^{\prime} \mathrm{W}\end{array}$ & 2414 & - & $\cdots$ & - \\
\hline $65-64$ & 09 Aug 65 & A.T. & $51^{\circ} 58^{\prime} \mathrm{N}, 132^{\circ} 50^{\prime} \mathrm{W}$ & 2652 & - & $\cdot$ & - \\
\hline $66-67$ & 16 Oct 66 & N.D. & $\begin{array}{l}\text { Tasu Inlet, Queen Charlotte Is. } \\
52^{\circ} 45^{\circ} \mathrm{N}, 132^{\circ} 06^{\prime} \mathrm{W}\end{array}$ & $220-350$ & Mud & $\cdots$ & 'Other fauna sparse' \\
\hline $66-76$ & 20 Oct 66 & A.T & $\begin{array}{l}\text { Off west entrance to Skidegate } \\
\text { Channel, Queen Charlotte Is. } \\
52^{\circ} 59^{\prime} \mathrm{N}, 133^{\circ} 06^{\prime} \mathrm{W}\end{array}$ & $1829-1370$ & $\begin{array}{l}\text { Hard } \\
\text { clay }\end{array}$ & $\cdot$ & Sponges, holothurians \\
\hline $67-54$ & 13 Aug 67 & C.D. & $\begin{array}{l}\text { Tasu Inlet, Queen Charlotte Is. } \\
52^{\circ} 40^{\prime} \mathrm{N}, 132^{\circ} 03^{\prime} \mathrm{W}\end{array}$ & 366 & $\begin{array}{l}\text { Sulphidic } \\
\text { mud }\end{array}$ & $\cdots$ & 'Other fauna sparse' \\
\hline $72-28$ & 06 Aug 72 & T.D. & $\begin{array}{l}\text { Off Draney Narrows, Rivers Inlet } \\
51^{\circ} 28.6^{\prime} \mathrm{N}, 127^{\circ} 34.5^{\prime} \mathrm{W}\end{array}$ & 316 & - & $\cdots$ & $\begin{array}{l}\text { Polychaetes, shrimps, } \\
\text { ophiuroids }\end{array}$ \\
\hline $72-29$ & 06 Aug 72 & T.D. & $\begin{array}{l}\text { S. end Edna Matthews Is., } \\
\text { Rivers Inlet } \\
51^{\circ} 34.9^{\prime} \mathrm{N}, 127^{\circ} 32.4^{\prime} \mathrm{W}\end{array}$ & 329 & - & $\cdot$ & $\begin{array}{l}\text { Polychaetes, shrimps } \\
\text { callanassids, Yoldia }\end{array}$ \\
\hline $72-31$ & 07 Aug 72 & T.D. & $\begin{array}{l}\text { Moses Inlet, Rivers Inlet } \\
51^{\circ} 48.8^{\prime} \mathrm{N}, 127^{\circ} 32.3^{\prime} \mathrm{W}\end{array}$ & 283 & $\begin{array}{l}\text { Mud, much } \\
\text { wood \& bark }\end{array}$ & $\cdots$ & $\begin{array}{l}\text { Polychaetes, shrimps, } \\
\text { Brisaster }\end{array}$ \\
\hline $72-32$ & 07 Aug 72 & T.D. & $\begin{array}{l}\text { Moses Inlet, Rivers Inlet } \\
51^{\circ} 44.7^{\prime} \mathrm{N}, 127^{\circ} 27.2^{\prime} \mathrm{W}\end{array}$ & 201 & $\begin{array}{l}\text { Soft mud, } \\
\text { some wood }\end{array}$ & $\cdots$ & $\begin{array}{l}\text { Polychaetes, gastropods, } \\
\text { sipunculids, Brisaster, } \\
\text { Molpadia }\end{array}$ \\
\hline $72-33$ & 07 Aug 72 & T.D. & $\begin{array}{l}\text { Moses Inlet, Rivers Inlet } \\
51^{\circ} 46.7^{\prime} \mathrm{N}, 127^{\circ} 23.5^{\prime} \mathrm{W}\end{array}$ & 247 & $\begin{array}{l}\text { Wood } \\
\text { debris }\end{array}$ & $\cdot$ & $\begin{array}{l}\text { Shrimps, Brisaster, } \\
\text { Ctenodiscus }\end{array}$ \\
\hline $72-34$ & 07 Aug 72 & T.D. & $\begin{array}{l}\text { Scandinavia Bay, Rivers Inlet } \\
51^{\circ} 38.9^{\prime} \mathrm{N}, 127^{\circ} 27.3^{\prime} \mathrm{W}\end{array}$ & 203 & $\begin{array}{l}\text { Soft, grey } \\
\text { mud }\end{array}$ & $\cdot$ & $\begin{array}{l}\text { Polychaetes, asteroids, } \\
\text { ophiuroids, Nuculana }\end{array}$ \\
\hline
\end{tabular}

below $200 \mathrm{~m}$ is colder, more saline and shows less seasonal fluctuation than in the southern group. This may reflect their proximity to deep water and a greater estuarine-driven circulation pattern. Pickard (1961) includes Belize and Seymour inlets in the intermediate group, but his diagrams show them hydrographically closer to the southern fjords. The southern group of fjords open onto Georgia Strait, which has restricted connection with the ocean at its northern and southern entrances, while the northern group have more open access to oceanic water through Hecate Strait and Queen Charlotte Sound.

\section{RESULTS}

The main part of the open coast records are shown in Fig. 2, with the mainland fjord occurrences given in 


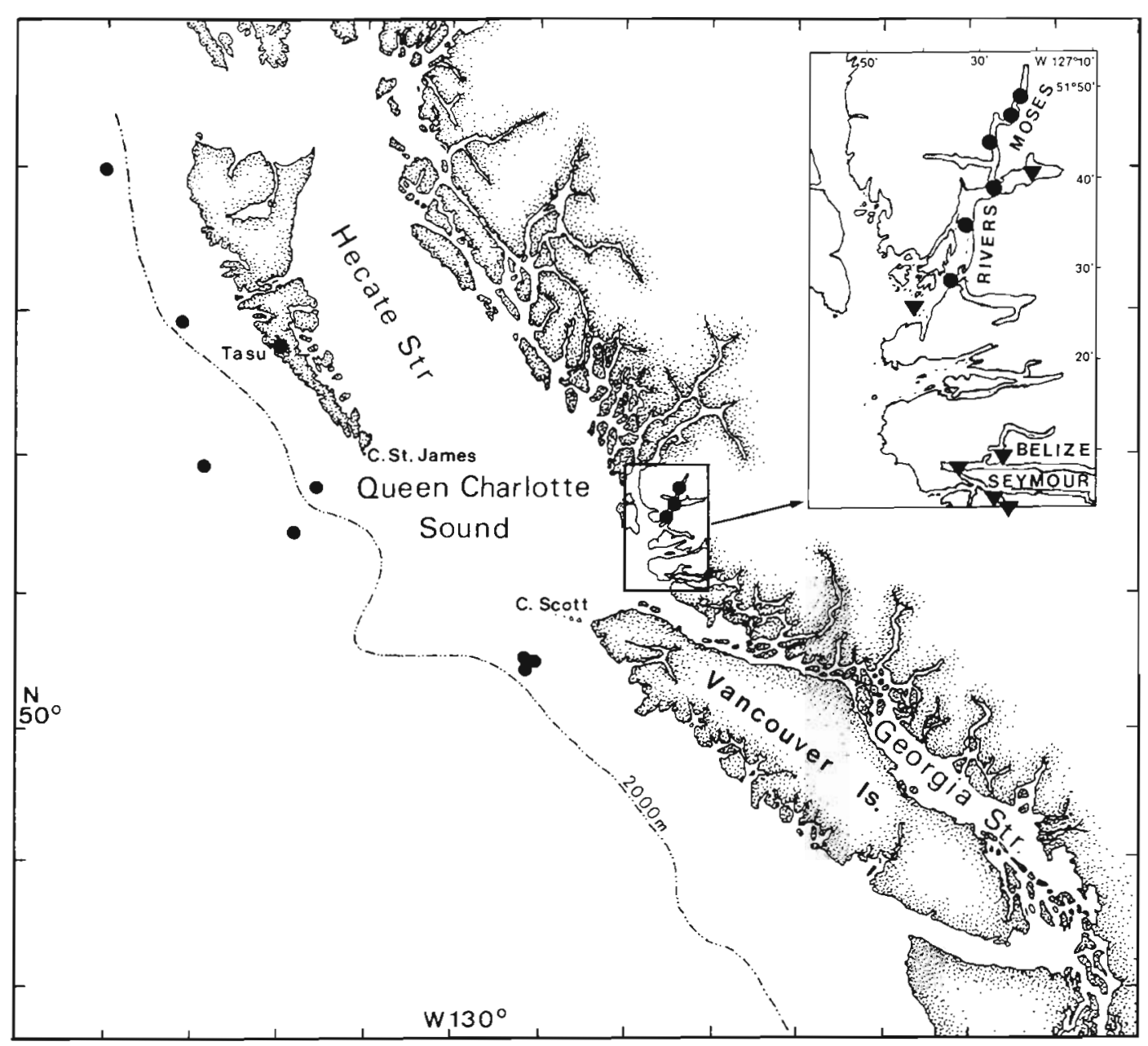

Fig. 2. British Columbian stations ( $\bullet$ where the pogonophore Polybrachia canadensis occurs. The position of Tasu Inlet on the west coast of Moresby Island (Queen Charlotte Islands) is indicated and the approximate $2000 \mathrm{~m}$ depth contour shown. The area containing Rivers Inlet, Moses Inlet, Belize Inlet and Seymour Inlet is drawn in more detail in the inset map: ( $\bullet$ pogonophores present; ( $\mathbf{\nabla}$ ) pogonophores absent

more detail on the inset. All the B.C. records of Polybrachia canadensis are listed in Table 1, with notes on bottom deposit and other macrofauna when these were recorded in the data files or field logs. Records for the other species of Pogonophora collected off British Columbia are given in Table 2 ; none of these ocurred in the fjord samples.

The new data show that Polybrachia canadensis is abundant in Rivers Inlet/Moses Inlet, as well as in Tasu Inlet, at depths much shallower than those at which it occurs in the open ocean, i.e. 201 to $366 \mathrm{~m}$ compared with 1372 to $2414 \mathrm{~m}$. Fig. 2 inset includes the stations sampled in Belize and Seymour inlets, where Pogonophora were not found. No Pogonophora occurred in the large number of samples that have been taken in the southern group of fjords and none were found in samples from the fjords along the west coast of Vancouver Island (see Fig. 1), Quantitative samples examined by the authors, taken from the southern fjords, including Knight and Bute Inlets and from several fjords along the west coast of Vancouver Island, also lack pogonophores. The negative records since 1950 can be accepted in view of the expertise of the principal scientists involved in the cruises and examination of samples.

\section{DISCUSSION}

The first example of Polybrachia canadensis (described as Heptabrachia canadensis) was taken by the Russian research ship 'Vityaz' northwest of the Queen Charlotte Islands in 2500 to $2600 \mathrm{~m}$ depth (Ivanov 1962). The first Canadian samples were recovered close to the entrance to Queen Charlotte Sound, off Cape St James and Cape Scott. These 
Table 2. Pogonophora other than Polybrachia canadensis occurring off British Columbia

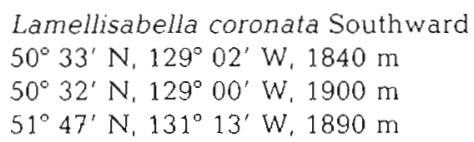

Siboglinum vancouverensis Southward $50^{\circ} 33^{\prime} \mathrm{N}, 129^{\circ} 02^{\prime} \mathrm{W}, 1840 \mathrm{~m}$ $50^{\circ} 32^{\prime} \mathrm{N}, 129^{\circ} 00^{\prime}$ W. $1900 \mathrm{~m}$ $51^{\circ} 47^{\prime} \mathrm{N}, 131^{\circ} 13^{\prime} \mathrm{W}, 1890 \mathrm{~m}$ $51^{\circ} 27^{\prime} \mathrm{N}, 131^{\circ} 48^{\prime} \mathrm{W}, 2400 \mathrm{~m}$

Siboglinum pusillum Ivanov $50^{\circ} 33^{\prime} \mathrm{N}, 129^{\circ} 02^{\prime} \mathrm{W}, 1840 \mathrm{~m}$ $50^{\circ} 32^{\prime} \mathrm{N}, 129^{\circ} 00^{\prime} \mathrm{W}, 1900 \mathrm{~m}$ $51^{\circ} 47^{\prime} \mathrm{N}, 131^{\circ} 13^{\prime} \mathrm{W}, 1890 \mathrm{~m}$ $51^{\circ} 27^{\prime} \mathrm{N}, 131^{\circ} 48^{\prime} \mathrm{W}, 2400 \mathrm{~m}$ $51^{\circ} 58^{\prime} \mathrm{N}, 132^{\circ} 50^{\prime} \mathrm{W}, 2675 \mathrm{~m}$

Siboglinum sp.

$50^{\circ} 33^{\prime} \mathrm{N}, 129^{\circ} 02^{\prime} \mathrm{W}, 1840 \mathrm{~m}$

$51^{\circ} 58^{\prime} \mathrm{N}, 132^{\circ} 50^{\prime} \mathrm{W}, 2675 \mathrm{~m}$

records are all from deep water locations near to the $2000 \mathrm{~m}$ contour and a recognised line of subduction. However, the rest of the fauna in these deep water open coast samples was typical of ordinary slope situations and not indicative of 'cool seep' conditions where there would be elevated sulphide or methane concentrations (Grassle 1986, p. 338-339). It was not expected that a deep-water pogonophore would also occur in the fjord locations, and the presence of the same species in Tasu Inlet and the Rivers Inlet complex is a remarkable discovery.

At the stations in Rivers Inlet/Moses Inlet the accompanying fauna was characteristic of soft mud and highly reducing conditions. Most of the samples contained large amounts of organic debris of terrestrial origin (mainly wood and bark) that would produce sediment conditions strongly favouring sulphatereducing bacteria, thus encouraging colonisation by pogonophores dependent on supplies of particulate sulphide. The stations sampled are remote from concentrated wood processing industries, such as pulp mills, and probably it is natural organic enrichment of the sediment that produces the conditions that favour the pogonophore populations.

Tasu Inlet, on the west side of Moresby Island, Queen Charlotte Islands, is only 25 nautical miles from the $2000 \mathrm{~m}$ contour and 42 nautical miles from the nearest deep-sea station where Polybrachia was collected. It is, however, comparatively shallow, the samples coming from 220 to $366 \mathrm{~m}$. The Tasu samples were strongly sulphidic on collection. Storage in isopropanol dissolved large amounts of elemental sulphur from the specimens, underlining the very rich nature of this habitat from the point of view of sulphur-axidising symbiosis. An environmental survey of Tasu Inlet (Goyette \& Thomas 1983) indicates little abnormality in the hydrographic conditions. The bottom water is cold $\left(7.4^{\circ} \mathrm{C}\right)$ and the salinity $(33.2 \%)$ indicates oceanic conditions. An earlier environmental assessment that included 2 trawl hauls at unspecified depths in Tasu Inlet (Brothers 1978) does not include any Pogonophora or other invertebrate animals that would be recognised as harbouring sulphur-oxidising symbionts (Southward 1987. Fisher 1990). However, the trawls may not have sampled the deep-water infauna. The dredge hauls taken by the Fishery Research Board invertebrate survey in Tasu Inlet dug deep into the soft mud and were dominated by tubes of the pogonophore Polybrachia; they contained little or no other macrofauna. Further investigation of this interesting inlet is desirable to see if the sulphidic conditions are due to local organic enrichment or if a geochemical source of sulphur is present.

As noted, Pogonophora have not been found in benthic samples taken in the southern B.C. fjords. There is no shortage of forest-derived organic debris in these places, so the absence of Pogonophora needs explaining. These fjords are separated from the open ocean by Georgia Strait, which is itself separated by narrow entrances from Puget Sound and from Queen Charlotte Sound. There are thus shallow zones of mixed waters between the open sea and the southern mainland fjords. Such conditions, including a region of higher temperatures on the bottom and greater distance from the open ocean, might inhibit spread of species such as Polybrachia canadensis, which appears to be a deep-sea stenotherm. The restriction of the pogonophores to the northern type fjords also accords well with their hydrography (Pickard 1961, 1975). The bottom waters in Rivers Inlet have temperatures of 6.4 to $6.5{ }^{\circ} \mathrm{C}$ and an almost unvarying salinity of $33.06 \%$; the upper part of Moses Inlet is slightly warmer on the bottom $\left(6.9\right.$ to $\left.7.7^{\circ} \mathrm{C}\right)$ and the salinity is 31.7 to $31.9 \%$. Seymour and Belize Inlets, where the pogonophore was not found, have a narrower entrance from Queen Charlotte Sound and a lesser estuarine-driven circulation. Temperatures are higher $\left(7.4\right.$ to $\left.7.9^{\circ} \mathrm{C}\right)$ and salinity lower $(29.0$ to $30.1 \%$ ) than in Rivers Inlet and seasonal variation is greater. The dissolved oxygen content of the deeper waters in Seymour and Belize Inlets is lower than in Rivers Inlet, sometimes less than $2.5 \mathrm{ml} \mathrm{l}^{-1}$, and there are suggestions that reductions of the estuarine circulation in these inlets may at times produce almost anoxic bottom conditions (Pickard 1961). Typical perviate Pogonophora such as Polybrachia live with most of their bodies buried deep in reducing sediments, to take advantage of the supply of sulphur compounds for energy production by the auto- 
trophic symbiotic bacteria (Southward \& Southward 1988). They do, however, require a good supply of oxygen, taken up from the bottom waters by the tentacle crown at the top end of the tube; this oxygen is required to maintain the autotrophic energetic processes of the bacteria as well as the ordinary metabolism of the host. Hence, seasonal or intermittent reductions in dissolved oxygen content of the deeper waters of a fjord would prevent establishment of a pogonophore population.

Pogonophores are also absent from the inlets along the west coast of Vancover Island. These fjords are shorter and shallower than the mainland fjords, and have shallower sills (Pickard 1963). They show considerable variations in oxygen content, and although the bottom waters are fully saline (32.1 to $33.3 \%$ ) they are warmer $\left(7.4\right.$ to $9.3^{\circ} \mathrm{C}$.) than the bottom waters of Rivers Inlet, and the deep water appears to undergo replacement in the latter part of the year when bottom temperatures inshore are higher. Such conditions must militate against colonisation by Polybrachia. There is ample forest-derived organic matter in certain of the Vancover Island fjords, enough to support high population densities of the clam Solemya reidi, which lives in symbiosis with chemoautrophic bacteria (Shepard 1986). The group of bivalves to which this species belongs is able to tolerate low oxygen levels and fluctuating environmental conditions, and its occurrence does not mean a habitat is suitable for perviate pogonophores.

It is interesting to note that 2 species of vesicomyid bivalves also occur along the B.C. continental slope, from the north end of the Queen Charlotte Islands to the south end of Vancouver Island, at depths of 589 to $1464 \mathrm{~m}$ (Bernard 1974). Species of this group have symbiotic autotrophic sulphur-oxidising bacteria in their gills (Fisher 1990), and representatives are known from areas of diffuse hydrothermal venting at Middle Valley on the Juan de Fuca-Explorer Ridge (Juniper et al. 1992). The absence of these bivalves from the Fishery Research Board stations in the fjords where the pogonophore occurs may be a result of the hydrographic regime in the fjords or the soft nature of the bottom deposit. There is evidence that the symbiotic bacteria in some vesicomyids are adapted to cooler environmental conditions than those occurring in the pogonophores examined (Southward 1991).

The most interesting feature of the B.C. pogonophore distribution is the extension of an apparently deep sea species into comparatively shallow fjords, so that the one abundant species covers an enormous depth range, from 2652 to $201 \mathrm{~m}$. In comparable climatic regions of the $N$. Atlantic region, that is, south of the Arctic Circle, the Norwegian fjords and adjacent open sea contain a number of species with different distribu- tion patterns, with a restricted depth range for each (Southward 1979). Even the largest and deepest Norwegian Fjords, Sognefjorden and Hardangerfjorden, are inhabited by comparatively small pogonophores (Webb 1965, Brattegard 1967). Other, smaller pogonophores do occur in B.C. waters (Table 2) but these are not dominant in the samples and do not extend into the fjords.

Thus, the abundance of a deep water pogonophore in the northern B.C. fjords, and the difference from the Norwegian fjords in this respect, merits further study. So far there has been little industrialisation of the northern B.C. fjords, apart from wood processing. Fish processing plants are present, as in Rivers Inlet, and there are mineral-based industries farther north at Bella Coola and Kitimat. The biology of these large fjords needs to be quantitatively characterised.

Acknowledgements. Most of the samples listed in Tables $1 \& 2$ were collected by the Fisheries Research Vessels 'G. B. Reed' and 'A. P. Knight' operating from the Pacific Biological Station, Nanaimo. We are grateful to Dr D. B. Quayle and the late F. R. Bernard for the samples and data sheets, and to Dr Quayle for his great help and advice in preparing this account. Thanks are due to Dr A. R. Fontaine and Dr V. Tunnicliffe for laboratory facilities at Victoria. Dr Tunnicliffe and Dr D. V. Ellis kindly provided additional data and benthic samples from B.C. locations. Part of the work was supported by a grant from the Leverhulme Trust to the Marine Biological Association.

\section{LITERATURE CITED}

Bernard, F. R. (1970). A distributional checklist of the marine molluscs of British Columbia; based on faunistic surveys since 1950. Syesis 3: 75-93

Bernard, F. R. (1971). British Columbia marine faunistic survey report: Brachiopoda. Tech. Pap. Fish. Res. Bd Can. 268: $10 \mathrm{p}$

Bernard, F. R. (1972). The genus Thyasira in Western Canada (Bivalvia: Lucinacea). Malacologia 11: 365-389

Bernard, F. R. (1974). The genus Calyptogena in British Columbia with a description of a new species (Bivalvia, Vesicomyidae). Venus 33: 11-22

Bernard, F. R. (1978). New bivalve molluscs, Subclass Pteriomorphia, from the Northeastern Pacific. Venus 37 : $61-75$

Bernard, F. R., Bourne, N., Quayle, D. B. (1967). British Columbia Faunistic Survey. A summary of dredging activities in Western Canada 1878-1968. Manuscr. Rep. Ser. Fish. Res. Bd Can. 920:61 p

Bernard, F. R.. Bourne, N., Quayle, D. B. (1968). British Columbia Faunistic Survey. A summary of dredging activities 1966-1967. Manuscr. Rep. Ser. Fish Res. Bd Can., 975, 6 p

Bernard, F. R., Bourne, N., Quayle, D. B. (1970). British Columbia Faunistic Survey. A summary of dredging activities 1967-1969. Manuscr. Rep. Ser. Fish Res. Bd Can. 1082: 7 p

Bernard, F. R., Quayle, D. B. (1973). British Columbia Faunistic Survey. A summary of dredging activities 1970-1972. Manuscr. Rep. Ser Fish Res. Bd Can. 1240: 11 p

Brattegard, T (1967). Pogonophora and associated fauna in the deep basin of Sognefjorden. Sarsia 29: 299--306 
Brothers, D. E. (1978). Marine environmental assessment of Tasu Sound, British Columbia, June, 1977. Fisheries and Environment Canada, Environmental Protection Service, Pacific Region, Regional Program Report 78-12: 33 p

Fisher, C. (1990). Chemoautotrophic and methanotrophic symbioses in marine invertebrates. C.R.C. critical Rev. Aquat. Sci. 2: 399-436

Grassle, J. F. (1986). The ecology of deep-sea hydrothermal vent communities. Adv. mar. Biol. 23: 301-362

Goyette, D., Thomas, M. (1983). Marine Environmental Assesment of Tasu Sound, British Columbia, 1982. Environment Canada, Environmental Protection Service, Pacific Region

Ivanov, A. V. (1962). New pogonophores from the eastern part of the Pacific Ocean. 2. Heptabrachia ctenophora sp. n. and Heptabrachia canadensis sp. n. Zoologicheski Zhurn. 41: 893-890

Juniper, S. K., Tunnicliffe, V., Southward, E. C. (1992). Hydrothermal vents in turbidite sediments on a northeast Pacific spreading centre: organisms and substratum at an Ocean Drilling Site. Can. J. Zool. (in press)

Pickard, G. L. (1961). Oceanographic features of inlets in the British Columbia mainland coast. J. Fish. Res. Bd Can. 18: 907-999

Pickard, G. L. (1963). Oceanographic characteristics of inlets of Vancouver Island, British Columbia. J. Fish. Res. Bd Can. 20: 1109-1144

Pickard, G. L. (1975). Annual and longer term variations of deepwater properties of the coastal waters of southern British Columbia. J. Fish. Res. Bd Can. 32: 1561-1587

This article was submitted to the editor
Schmaljohann, R., Flügel, H. J. (1987). Methane oxidising bacteria in Pogonophora. Sarsia 72: 91-98

Shepard, P. M. G. (1986). The benthic ecology of the gutless bivalve, Solemya reidi. M. Sc. thesis, University of Victoria, Canada

Southward, A. J. (1991). Effect of temperature on autotrophic enzyme activity of bacteria symbiotic in clams and tube worms. Kieler Meeresforsch., Sonderh. 8: 245-251

Southward, A. J., Dando, P. R. (1988). Distribution of Pogonophora in canyons of the Bay of Biscay: factors controlling abundance and depth range. J. mar. biol. Ass. U.K. $68: 627-638$

Southward, A. J., Southward, E. C. (1988). Pogonophora: tube-worms dependent on endosymbiotic bacteria. ISI Atlas of Science: Animal and Plant Sciences 1988: 203-207

Southward, E. C. (1969a). New Pogonophora from the northeast Pacific Ocean. Can. J. Zool. 47: 395-403

Southward, E. C. (1969b). Growth of a pogonophore: a study of Polybrachia canadensis with a discussion of the development of taxonomic characters. J. Zool., Lond. 157: $449-467$

Southward, E. C. (1979). Horizontal and vertical distribution of Pogonophora in the Atlantic Ocean. Sarsia 64: 51-55

Southward, E. C. (1987). Contribution of symbiotic chemoautotrophs to the nutrition of benthic invertebrates. In: Sleigh, M. (ed.) Microbes in the sea. Ellis Horwood, Chichester, p. 83-118

Webb, M. (1965). Notes on the distribution of Pogonophora in Norwegian fjords. Sarsia 18: 11-15

Manuscript first received: January 30,1992

Revised version accepted: April 21, 1992 